\title{
Inventing critical development: A Brazilian geographer and his Northern networks
}

Federico Ferretti federico.ferretti@ucd.ie

Breno Viotto Pedrosa brenoviotto@hotmail.com

\begin{abstract}
This paper addresses a corpus of unpublished sources in a first attempt to reconstruct the exile networks of Brazilian geographer Milton Santos, placing his geographical and political work in the context of present-day debates on development, anti-development and critical development. Our main argument is twofold: first, we argue that Santos played important although poorly understood roles in the debates which shaped both Anglophone and French-speaking critical geographers in the 1960s and 1970s. Far from being passive receivers of ideas from the Global North, Southern scholars like Santos contributed to shape worldwide concepts in critical studies on development and underdevelopment. Second, the ideas spiralling out of Santos' networks can still nourish present-day scholars in development and critical development theories who are willing to criticize the 'ideology of development' without forgetting the material existence of poverty and socio-spatial marginalization. Finally, Santos' biography and networks provide an example of cosmopolitan and multilingual intellectual work that can provide insights for the present-day the internationalization of critical and radical geographies.
\end{abstract}

Keywords: Milton Santos; Critical Geographies; Critical Development; Exiles; Archives.

Federico Ferretti \& Breno Viotto Pedrosa, 2018, "Inventing critical development: a Brazilian geographer and his Northern networks", Transactions of the Institute of British Geographers [early view https://onlinelibrary.wiley.com/doi/full/10.1111/tran.12241] 
"[At the AAG conferences] we used to go to objectionable sessions, and ask difficult questions. Milton loved doing this. His French-Brazilian accent intimidated them. One time he put his hand up to ask a question. The lecture theater had a dark brown wall. The speaker either didn't see Milton, or deliberately ignored him. I said 'they cannot see your hand because it's black'. He took a handkerchief from his jacket, front pocket and waved that vigorously. The speaker had to answer!"

Richard Peet, Interview with the authors, 25 April 2017

This paper addresses the biography and international networks in the Global North of the Brazilian geographer Milton Almeida dos Santos (1926-2001), one of the major figures in radical and critical geographies in Latin America in the second half of the twentieth century. One of the contentions of this paper is that his works deserve to be better known and re-read. Santos' moves and connections merit excavation, as his works and networks played a role in the evolution of a radical development geography. This paper extends recent literature bringing studies of this figure to the English-speaking public (Melgaço 2017; Melgaço and Prouse 2017, Bernardes et al. 2017). Our argument is twofold: first, we argue that Santos' life and work demonstrates that in geography and development studies the so-called 'underdeveloped world' was not a mere receptor of scientific theories elaborated in the North. Rather, Southern scholars 'taught' Northern colleagues, nourishing their ideas on development and underdevelopment from original perspectives. Second, we suggest the ideas coming out of Santos' networks can still contribute to present-day critical development theories, by providing analytical tools that help to criticise the ideology of development' without forgetting the material existence of poverty and socio-spatial marginalisation, as some critiques to development are considered to do (Peet and Hartwick, 2015). Santos deemed geography a fundamental tool of mobilisation, considering space, territory and society as a whole to be studied and modified by way of an 'active geography' (Bernardes et al., 2017). His ideas anticipated theories of engagement that are present in recent scholarship on critical geographies in Latin America (Finn and Hanson 2017).

Santos' friend and collaborator David Slater argued that the complex set of theories known as 'dependency theory' was a way through which the South 'theorised back'. He also noted that 'the fact that associated modes of reflection emerged in other parts of the South during the same years

Federico Ferretti \& Breno Viotto Pedrosa, 2018, "Inventing critical development: a Brazilian geographer and his Northern networks", Transactions of the Institute of British Geographers [early view https://onlinelibrary.wiley.com/doi/full/10.1111/tran.12241] 
and that the ideas of the Latin American writers spread to other parts of the Third World expressed the depth of this challenge' (Slater 1993, 430). Yet, the valuable international literature which addresses the dependency school as the most original product of South American thinking in that period (Blomström and Hettne 1984; Kay 1989) generally neglects geography and rarely quotes Santos, apart from Charles Gore, who argued that Santos' work provided a 'much more sophisticated view of the process of change in dependent countries' (Gore 1984, 135). If we consider other critics of 'radical development' such as Stuart Corbridge - who argued that 'for the followers of Frank and Wallerstein capitalism has been essentially the same [in time] and it remains essentially the same [in space]' (Corbridge 1986, 245) - Santos' work stands as an example of how, in this 'counter-theorising' from the South, more nuanced concepts were elaborated to make sense of complexity and spatial differences. We draw upon Magnus Blomström's and Björn Hettne's argument that 'traditional ... thinking on development is based on experiences which are specific to the western world and that the claim to universal validity must be repudiated ... it is important to consider the voices from the periphery' (Blomström and Hettne 1984, 4). Santos dealt with dependency wider debates, as shown by his references to authors like André Gunder Frank, and by his experience as a planner in Bahia from 1962 to 1964, interested in the elaborations of Celso Furtado and other CEPAL intellectuals. The CEPAL (Comisión Económica para América Latina y el Caribe) was a special UN agency for Latin America and a centre for international debates on growth poles and dependency theory (Kay 1989). Despite these influences, Santos' conceptions of dependency proved to be original; as we explain below, his ideas on the 'shared space' circulated significantly in English-speaking scholarship (Power and Sidaway 2004; Santos 1979).

To understand Santos' works, it is essential to consider his transnational trajectory. Like other Brazilian geographers - including Josué de Castro - Santos had to flee from Brazil after the establishment of the military dictatorship in 1964. He lived and worked in several countries in Europe, Africa, and North and South America, where he became acquainted with critical, radical and anti-colonialist geographers such as Richard Peet, Neil Smith, David Slater, Joe Doherty and others in the English-speaking geographic communities, and Yves Lacoste, Jean Dresch, Bernard

Federico Ferretti \& Breno Viotto Pedrosa, 2018, "Inventing critical development: a Brazilian geographer and his Northern networks", Transactions of the Institute of British Geographers [early view https://onlinelibrary.wiley.com/doi/full/10.1111/tran.12241] 
Kayser and many others in France. These connections led to Santos' contributions to early numbers of the most important journals of critical geography of the 1960s and the 1970s, such as Hérodote and Antipode. Santos exerted significant, but hitherto unacknowledged, roles across these networks of radical geographers. His work shaped debates in social geography, studies of poverty and underdevelopment in what was then called the 'Third World'. Following the global networks, partnerships and receptions of thinkers like Santos can help to eliminate the so-called 'impasse' (Schuurman 1993) experienced by development studies in the last two decades. His example questions some commonplace assumptions about development as a merely Western and neocolonial ideology. Over the last 20 to 25 years, little attention has been paid to the transnational and multilingual circulation of these concepts. Drawing upon critical approaches to development, de-colonialism and post-colonialism, we aim to contribute to a research agenda that goes beyond the categories of development and anti-development (Power 2003; Sidaway 2007; Simon 1997 and 2007). This implies seeking convergences between different critical approaches, such as dependency theory, Marxism, poststructuralism and anarchism, a task to which Santos' works can contribute.

This paper explores the archives of Milton Santos, which are housed at the São Paulo Instituto de Estudos Brasileiros (IEB), a collection which has been only recently opened to researchers. We analyse his unpublished correspondence with Northern scholars, together with his works published in French and English. It is difficult to assess the amount and variety of the materials held in Santos' archives (mainly Santos' books, correspondences and work notes) because their inventory is still ongoing, but the size of the collection is impressive: the archival unpublished items registered in the provisional inventory (letters and work notes) alone were almost 1,700 up to May 2017. An established literature on the archival work in historical geography considers archives not only as the bulk of sources but also as complex and multifaceted research objects in themselves (Ashmore, Craggs and Neate 2012; Withers 2004; Keighren 2012), and the case of Santos' archives is already a matter of interest for Brazilian scholarship. According to Flávia Grimm, Santos' archives preserve the original organization of the materials, such that 'the materials' arrangement maintains the order of [Santos'] ideas' (Grimm 2011, 181). We also recognize the epistemological and

Federico Ferretti \& Breno Viotto Pedrosa, 2018, "Inventing critical development: a Brazilian geographer and his Northern networks", Transactions of the Institute of British Geographers [early view https://onlinelibrary.wiley.com/doi/full/10.1111/tran.12241 ] 
political significance of reconstructing biographies of critical geographers, what Trevor Barnes defines as a 'useful addition to science studies [because] it emphasizes both the rhetorical and constructed nature of the stories that are told, as well as the role of the biographer in telling them' (Barnes 2001, 425).

In the first part of this paper, we define the debates on development and anti-development which constitute the theoretical framework in which we address Santos' works. In the second part, we reconstruct Santos' trajectory from his region of origin, Bahia, to his exile in Europe and North America. In the third part, we analyse Santos' French and English-speaking networks and his contribution in stimulating geographers' interests in poverty and underdevelopment.

\section{Contentious developments}

\subsection{Beyond anti-development?}

In the last 20 years, an abundant international literature has promoted substantial debate on the openings and limits of the concepts of development and underdevelopment as they were formulated in the aftermath of the Second World War. The idea of underdevelopment paralleled the invention of the 'Third World', a definition that owed much to the 'new geopolitical imagination' of the Cold War (Dodds 2008, 3). In the 1990s, the field of development studies fell into what Frans Schuurman calls an 'impasse' (Schuurman 1993) with the acknowledgement of the 'evolutionist, universalist and reductionist dimension' (Schuurman 2008, 14) of the dominant version of these concepts. According to its critics, development failed, and for some its success would have been even worse than its failure. Intellectuals from Europe and Latin America, including Wolfgang Sachs, Arturo

Escobar and Gustavo Esteva, considered development and underdevelopment as inventions by one actor of the Cold War, - the Western Block - after US President Harry Truman implied that 'two billion people became underdeveloped' in a speech on 20 January 1949 (Esteva 1992, 7). This 'invention of underdevelopment' $(1992,6)$, together with the 'ideology of development', served to 'depoliticize poverty' and was in fact a form of neo-colonialism (Power 2003, 87).

This critique found a strong theoretical basis thanks to the book of Columbian anthropologist

Federico Ferretti \& Breno Viotto Pedrosa, 2018, "Inventing critical development: a Brazilian geographer and his Northern networks", Transactions of the Institute of British Geographers [early view https://onlinelibrary.wiley.com/doi/full/10.1111/tran.12241] 
Arturo Escobar, Encountering Development (1995), where Escobar applied the intellectual tools of poststructuralist critique to the 'discourse' of development, stressing the 'westernisation of the world' which such discourse perpetuated, and indicating local cultures as a starting point to resist a unique idea of development. Authors like Escobar and Esteva considered Marxist Southern intellectuals such as the 'Latin American dependency theorists' (Esteva 1992,11) as accomplices of the development ideology, and aligned themselves to the so-called 'de-colonial turn' led by South-American scholars such as Walter Mignolo, Enrique Dussel and Edgardo Lander (Mignolo 2011; Dussel et al., 2000).

The field of geography was influenced by these interdisciplinary debates, thanks to geographers' commitment to the topics of the Global South and development. Marxist geographers, drawing on the idea of uneven development as a necessary condition of capitalism, did not follow the poststructuralist critiques of development and generally continued to use this concept, even if formulated in ways more attentive to ecology and indigenous movements (Peet and Watts 1996; Peet and Hartwick 2009) and to the 'possibility to overlap different approaches' (Harvey 2006, 74). Other geographers committed to postcolonial studies and critical research on the Global South, including Marcus Power, James Sidaway and David Simon, analysed the spaces of 'antidevelopment' and called for a dialogue between the different critical approaches known through the vague definitions of 'anti-development, beyond-development, post-development' (Power 2003, 83) and the wider frame of postcolonial, de-colonial and subaltern studies, matching contemporary statements by development scholars such as Aram Ziai (2015). Simon stated that it was necessary to remain critically engaged with development issues in order to 'help the approximately 1.2 billion people living in absolute poverty to improve their position' (Simon 1997, 184). Simon, albeit criticizing the anti-development and post-development positions, recognized that there was 'some basis for a convergence in critical development studies' (Simon 2007, 206). If Simon refuses an essentialization of development, also the essentialization of its contrary is to be avoided: 'as with development, post-development is not a single or coherent theoretical position or critique' (2007, 207). Finally, "beneath the terminological differences and the apparently profound ruptures of epistemology, discourse and practice between "development" and anti/post-development that they

Federico Ferretti \& Breno Viotto Pedrosa, 2018, "Inventing critical development: a Brazilian geographer and his Northern networks", Transactions of the Institute of British Geographers [early view https://onlinelibrary.wiley.com/doi/full/10.1111/tran.12241 ] 
reflect, there are substantial commonalities, overlaps and contradictions. Progressive, radical and critical approaches to development have far more in common with post development than what separates them' (2007, 214). A similar position was taken by Slater (2011), who called for the rescuing of the category of imperialism, a topic familiar to Santos as well.

Feminist and postcolonial geographers criticized different features of Western and Northern discursive constructions of the South, including that of 'tropicality'. According to Felix Driver and Brenda Yeoh, 'the identification of the Northern temperate regions as the normal, and the tropics as altogether other-climatically, geographically and morally-became part of an enduring imaginative geography, which continues to shape the production and consumption of knowledge in the twenty-first century world' (Driver and Yeoh 2000, 1). Simon observes that 'postdevelopment is generally positioned as postcolonial, in explicit or implicit contradistinction to the apparently colonial or neocolonial nature of conventional and other progressive approaches' (Simon 2007, 210). More specifically, Parvati Raghuram and Clare Madge claim the possibility of establishing postcolonial development geographies, based first on the consciousness of the situated nature of all knowledge. The possibilities of decolonizing development geographies are thus defined by a range of conditions, such as the self-questioning of the scientific authority. 'A postcolonial method demands that research questions should be produced in dialogue so that project beginnings are embedded within and take account of the priorities of the researched and not delimited by the concerns of the northern "experts"' (Raghuram and Madge 2006, 276). Finally, Power and Sidaway argue that, in the second half of the twentieth century, a shift occurred between the former tropical and colonial geographies and the geographies of development. 'Today, therefore, recognition that development is but one perspective ... can open up other visions' (Power and Sidaway 2004, 594), going towards 'a new metageography of development' (Sidaway 2007).

Drawing on this convergence between 'anti', 'post' - and 'beyond' development and broader critical and radical approaches, this paper aims to contribute to the 'de-colonization' of social sciences, to the history of critical geographies and to the wider field of development studies by rediscovering forgotten networks and authors from the South, such as Santos, who provided original and still

Federico Ferretti \& Breno Viotto Pedrosa, 2018, "Inventing critical development: a Brazilian geographer and his Northern networks", Transactions of the Institute of British Geographers [early view https://onlinelibrary.wiley.com/doi/full/10.1111/tran.12241 ] 
helpful ideas for these fields of study.

\subsection{Geography, and 'voices from the South'}

The various tendencies represented in the rich international literature we have briefly reviewed tend generally to focus more on the roles played by Northern scholars in building development and underdevelopment as scientific ideas since the beginning of the Cold War, with some exceptions such as the book Fifty Thinkers in Development edited by Simon (2006). Nevertheless, authors such as Power and Sidaway acknowledged the heterogeneous nature of the dependency schools, arguing that "tropical geography's transformation (its "degeneration") into development geography came to be refracted into differing channels of modernization theory and a radical development geography of dependency. In turn, these too have splintered' (Power and Sidaway 2004, 592). Interrogating this splintering through the experience of Santos can shed light on these processes and provide new interpretations. Power and Sidaway, discussing the influence of geographer Keith Buchanan (1924-2002), noticed in this context some early occurrences of the notion of antidevelopment. 'The radical journal Antipode soon began publishing articles about geography and development. These and others were concerned to explore the geographies of dependency. One article, by Terry McGee (who had been Buchanan's student at Victoria University, Wellington), was subtitled "Towards a geography of anti-development"” (Power and Sidaway 2004, 594). Thus, an early occurrence of the term anti-development can be found in a circuit far from later poststructuralist tendencies. In the next section, we will show the role Santos played in these publications; now, it is worth noting that, in the collective book Radical Geographies, edited by Peet in the same year (1977), Buchanan showed the reasons for this critique of the 'ideology of development', a term he defined as a 'dirty word'. According to Buchanan, 'every reasonable and enlightened person was, it was implied, for "development" ... But a decade or so ago, as the "underdeveloped" were administered larger and larger doses of the magic medicine of "development", they began to notice how this therapy always enriched the developers and impoverished the supposed beneficiaries of the process' (Buchanan 1977, 363). Thus, development should not be confused with economic growth, and should not be the mere application of Northern models or official definitions by Southern authoritarian governments such as the Brazilian military

Federico Ferretti \& Breno Viotto Pedrosa, 2018, "Inventing critical development: a Brazilian geographer and his Northern networks", Transactions of the Institute of British Geographers [early view https://onlinelibrary.wiley.com/doi/full/10.1111/tran.12241] 
dictatorship (1964-1985).

In the meantime, 'Milton Santos (1979) had written of The shared space .... identifying dualistic circuits of the urban economy during the 1970s in Latin American, African and Asian cities ... Santos' dualistic espace partagé are supplemented by graduated and increasingly bounded spaces, notably the free trade or special economic zone and industrial estate plugged directly into global production networks' (Sidaway 2007, 352). These ideas of 'shared space' and 'double circuit' (Santos 1979), often neglected or even criticized in international literature, can still contribute to our understanding of why, as Matthew Sparke argued, the Global South is everywhere and cannot be easily identified with simple geographical locations (Sparke 2007). The concept of shared spaces envisaged different speeds in the working of the spatial circuits of, respectively, higher and lower classes in the cities of then 'underdeveloped' countries, as well as more internationally integrated and more disconnected economic activities. Discussing the construction of the theories launched by critical geographers of those years can contribute to present challenges for 'situating theory' (Raghuram and Madge 2006, 280) as a condition for doing research in the South, and the possibility for the involved scholars to 'not be dependent in theory' $(2006,283)$.

\section{From the North-East (of Brazil) to the Global North}

Santos was born in 1926 to a family of Afro-descendant schoolteachers in Bahia. There, he witnessed the problems of poverty at a young age and had to face racism: due to the discriminations that Black students suffered at the prestigious Polytechnic School, he decided to give up his projected studies in Engineering and took instead his degree in Law at the Federal University of Bahia (Cirqueira 2010, 5; Mamigonian 2004, 134). At university, he was denied a candidature for president of the Student Union by the university section of the Communist Party, for similar reasons. As Santos recollected: 'They refused me the possibility of being the president ... pretending that a Black would have experienced difficulties in negotiating with the authority. I felt very disappointed with this' (Buss et al. 2011, 180). These early political deceptions inspired Santos' critical positions toward political parties. Some years later, he approached politics 'through journalism' $(2011,181)$, remaining an independent Marxist without any party affiliation.

Federico Ferretti \& Breno Viotto Pedrosa, 2018, "Inventing critical development: a Brazilian geographer and his Northern networks", Transactions of the Institute of British Geographers [early view https://onlinelibrary.wiley.com/doi/full/10.1111/tran.12241 ] 


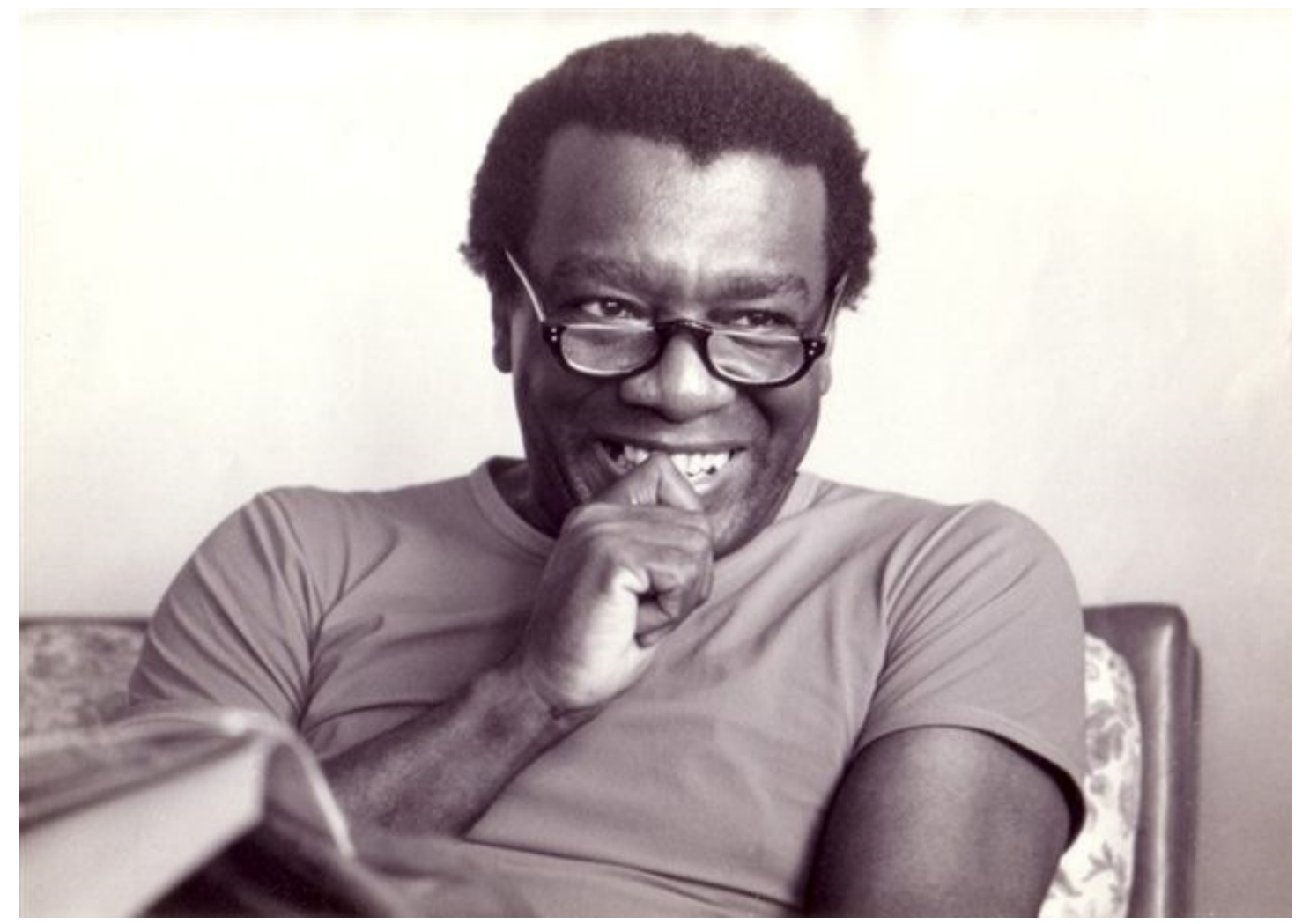

Fig. 1. Photo of Milton Santos [source www.miltonsantos.com.br]

Whilst addressing the problem of Blackness for Santos' itinerary would be worthy of a specific paper, Santos constantly denounced the racism he faced in Brazil and abroad, also claiming the experience of 'having been a Black in four continents, and in each one being black is different' (Santos 2002, 157). An anecdote he often told concerned a visiting fellowship at University College London in 1972 that he decided to interrupt following the difficulties he had in finding a flat to rent, which he attributed to racial discrimination: 'It was impossible to find an accommodation due to the extreme racism of the English' (Buss et al. 2011, 191). Later, Santos addressed the traditional social subordination of Afro-descendants in Brazil, denouncing their 'mutilated citizenship' and evoking 'a form of Brazilian-style apartheid, against which we must fight urgently if we really want Brazilian society to be inclusive' (Santos 2002, 157). Nevertheless, Santos never joined Black movements and remained wary of initiatives exclusively focusing on racial issues, considering them as part of a wider social question (Cirqueira 2010).

Federico Ferretti \& Breno Viotto Pedrosa, 2018, "Inventing critical development: a Brazilian geographer and his Northern networks", Transactions of the Institute of British Geographers [early view https://onlinelibrary.wiley.com/doi/full/10.1111/tran.12241] 
Santos' interest for geography was stimulated first by de Castro (Contel 2014) and then by the 1956 eighteenth International Geographical Congress held in Rio de Janeiro, where he had the occasion to meet most of the international geographers whose works circulated in Brazil, especially the French. The work of French geographers had been paramount in the development of Brazilian academic geography since the opening of the University of São Paulo in 1934 and the Federal University of Rio de Janeiro in 1935 (Borzacchiello 2016). At the 1956 congress, Santos became acquainted with Jean Tricart (1920-2003), geomorphologist and Marxist, who later became his collaborator and supervisor for the doctorate Santos obtained in Strasbourg in 1958. Among the other participants at the meeting were Jacqueline Beaujeu-Garnier (1917-1995) and Jean Dresch (1905-1994), the French geographer committed to the anti-colonial struggle of North-African peoples (Dresch 1979), who also became a correspondent of Santos. ${ }^{1}$

While accomplishing his doctorate and doing his first sojourns in France, Santos worked as a Professor of Geography at the Catholic University of Bahia from 1956 to 1960; in 1961, he was appointed as Chair of Geography at the Bahia Federal University. In Salvador, Santos was one of the leaders of the Laboratory of Geomorphology and Regional Studies, supporting an idea of urban geography that considered both the city and its regional impact, inspired by French regional geography. Santos pioneered both the application of this set of ideas to Bahia and, later, a regional approach to 'underdeveloped' cities (Buss et al. 2011; Mamigonian 2004). From 1959, Santos started to publish in the major French geographical journals, such as Information Géographique, Annales de Géographie, Cahiers d'Outremer and Revue de Géographie de Lyon (Santos 2001) on topics of urban geography and underdevelopment. After the 1964 military coup, Santos was arrested as a political opponent and after his release fled to France, where he lectured at the University of Toulouse from 1964 to 1967. Santos was among the leaders of the Institut d'étude du développement économique et social (IEDES) collaborating to its journal Tiers Monde, in which he would publish 22 papers from 1967 to 1980 (Santos 2001). Santos declared himself

\footnotetext{
${ }^{1}$ Instituto de Estudos Brasileiros (hereafter IEB), MS-RS85-027-B, Dresch to Santos, 19 October 1985.

Federico Ferretti \& Breno Viotto Pedrosa, 2018, "Inventing critical development: a Brazilian geographer and his Northern networks", Transactions of the Institute of British Geographers [early view https://onlinelibrary.wiley.com/doi/full/10.1111/tran.12241]
} 
uncomfortable with the superficial views of French mainstream geography towards the specificities of the Third World and tried to promote public engagement on poverty and underdevelopment through his Toulouse courses on hunger in 'underdeveloped' cities, inspired by de Castro's Geography of Hunger (Buss et al. 1991, 138).

Santos' work participated in pioneering efforts to introduce these topics in French-speaking geography, paralleling claims by Yves Lacoste who argued that developmental issues, mostly addressed by economists and sociologists but neglected by French geographers, 'might enrich Geography' (Lacoste 1962, 414). French 'classical' geography was traditionally wary of epistemological innovation and political commitment (Robic, Tissier and Pinchemel 2011), what explains its delay in engaging with issues of poverty. This concern was officially endorsed only in 1967 by a special issue of the Annales de Géographie, 'Geography and Development', edited by Dresch, Lacoste, Philippe Pinchemel, Paul Moral and Pierre Monbeig, another French geographer involved in the French missions in Brazil. In Moral's paper, Santos was quoted as the author of reference for Brazilian cities (Moral 1967). If we consider that the issue's editors were all Santos' acquaintances and that, before this publication, Santos had already published 11 papers in major French scholarly journals between 1959 and 1967 (Santos 2001), it is possible to argue that the Brazilian geographer played a pioneering role in calling the attention of his French colleagues to poverty and 'underdevelopment'.

With Dresch, Tricart and the urban geographer Michel Rochefort (1927-2015), Santos attended the regional IGU conference at Mexico City in 1966, showing his special interest in matters of planning and soil use to challenge underdevelopment (Bomfim and Vargar 2014). In 1967-68, Santos lectured at the University of Bordeaux, where an international conference on 'Space regionalization in Brazil' was organized by the CNRS Centre for Studies on Tropical Geography (directed by Santos' friend Guy Lasserre). It was attended by many French geographers who had worked in Brazil, such as Monbeig, George, Rochefort, Bernard Kayser and Pierre Deffontaines (Bomfim 2015; Ferretti 2014). It is worth noting that, despite the importance of tropicalism and imperial legacies in French geography (Bowd and Clayton 2005), an academic tropical geography was fully

Federico Ferretti \& Breno Viotto Pedrosa, 2018, "Inventing critical development: a Brazilian geographer and his Northern networks", Transactions of the Institute of British Geographers [early view https://onlinelibrary.wiley.com/doi/full/10.1111/tran.12241 ] 
established in France only in the 1950s. According to Paul Claval, it served 'postcolonial polices of cooperation' (Claval 2005, 300) rather than imperial endeavours. Nevertheless, its focus on agricultural development helps to explain Santos' gradual estrangement from these circuits, given his interests in problems of urbanism and planning.

From 1968 to 1971, Santos lectured at the Paris Sorbonne and worked at the IEDES central offices. In 1971 his book Cities in Underdeveloped Countries in 1971 was translated into French (Grimm 2011, 175-176). In the same year, he published in French The Geographer's Work in the Third World. This book criticized the traditional empiricism and anti-theoretical position of classical French geography (see Orain 2009), arguing that thinking space theoretically allows scholarship to tackle the challenges of underdevelopment (Santos 1971). Santos was also the editor of a special number of Tiers Monde on the 'Organisation of space in underdeveloped countries', which included contributions by John Friedmann, Terry McGee and Lloyd Rodwin, who composed the first cluster of Santos' Anglophone networks. Eventually, Rodwin was responsible for his invitation at MIT in 1972 (Contel 2014, 387), while McGee would remain a life-long Santos' collaborator, as witnessed by his letters to the Brazilian geographer sent after his return to Brazil, inviting Santos to take part in a UGI group ${ }^{2}$ and exchanging opinions with him on their publications. $^{3}$

After May 1968, Santos became interested in the structuralist Marxism developed by Louis Althusser (1918-1990), whom Santos considered as an inspiration for the idea of social formation. According to Richard Peet and Elaine Hartwick, this notion had implications for the concept of uneven development, because 'social formations take shape in the articulation of several modes of production and so the economic dynamic of a specific society has a group of often conflicting developing and under-developing tendencies' (Peet and Hartwick 2015, 187). Santos also collaborated with French geographer Jacques Lévy in the creation of the journal Espace-Temps, in origin also inspired by Althusser (Pedrosa 2013, 232). In fact, if Santos was initially linked to the

\footnotetext{
${ }^{2}$ IEB, MS-RS83-029, McGee to Santos, 16 February 1983.

${ }^{3}$ IEB, MS-RS84-047, McGee to Santos, 24 October 1984.
}

Federico Ferretti \& Breno Viotto Pedrosa, 2018, "Inventing critical development: a Brazilian geographer and his Northern networks", Transactions of the Institute of British Geographers [early view https://onlinelibrary.wiley.com/doi/full/10.1111/tran.12241 ] 
discourse of development and of the growth poles, the progressive radicalization of his thinking led him to criticise this discourse and to focus on the 'development of underdevelopment'. We explore this further in the following section.

\section{Networking for the Global South}

\subsection{Anglophone networks}

In 1972, Santos joined the Special Program for Urban and Regional Studies (SPURS) at the Massachusetts Institute of Technology (MIT), an international centre addressing planning, economy, urban studies, architecture and geography in 'underdeveloped' countries. From 1972 to 1973, Santos lectured at the University of Toronto, and according to Contel $(2014,398)$, it was there that he wrote the Shared Space, published in French in 1975 and then in English and Portuguese in 1979. A complete curriculum vitae redacted by Santos in the last period his life (Santos 2001) allows us to follow the academic wanderings of his exile, including a three-month appointment at the University of Lima (Peru), in connection with the International Labour Organization (Buss et al. 2011, 138-39; Silva 2011, 178). This collaboration with the ILO allowed Santos to visit various African countries, such as the Ivory Coast, Benin, Ghana, Togo, and Tunisia, and Latin American countries such as Cuba and Colombia (Contel 2014, 399). In 1974, he lectured at the Centre of Development Studies in the Central University of Venezuela, and from 1974 to 1976 he was at the University of Dar es Salaam, in Tanzania, working on a socialist development project that also involved David Slater. In a paper published for Tiers Monde (Santos 1978), Santos expressed his critical views on socialist modernization in Tanzania, drawing on his theory of sociospatial formation (discussed below) calling for the consideration of space in social theory and for the necessity of avoiding excessive functional concentration in Dar es Salaam. During these years, Santos developed his pragmatic approach to theories: solutions, he argued, are not ready to be applied but should be adapted to historical and geographical local situations, including social and cultural traditions. For Santos, neither socialism nor capitalism could be exported to the Third World as they stood elsewhere, without considering the different contexts of their application.

In 1976-77, Santos worked as a lecturer in Geography and Planning at Columbia University in New

Federico Ferretti \& Breno Viotto Pedrosa, 2018, "Inventing critical development: a Brazilian geographer and his Northern networks", Transactions of the Institute of British Geographers [early view https://onlinelibrary.wiley.com/doi/full/10.1111/tran.12241 ] 
York City. In his recollections, he evoked an appointment he was offered to found 'a new university in Biafra' (Buss et al. 1991, 196), a region in which he had expressed interest, as witnessed by his notes on Nigerian geographer Akin Mabogunje with whom he was in touch. ${ }^{4}$ Santos refused this appointment because, concurrently, he had the occasion to come back to his country thanks to an invitation as a visiting professor in Rio de Janeiro by Bertha Becker (Lévy 2007, 26). Becker (19302013) was a well-established Brazilian academic geographer and her support matched the generalized endorsement of Santos by the community of Brazilian geographers. Santos' popularity was increasing after the 1978 Fortaleza Congress of the Association of Brazilian Geographers (AGB), where a part of Brazilian geography took a leftist turn thanks to the introduction of radical geography to which Santos contributed (Borzacchiello 2016) despite the lasting presence, until 1985, of the dictatorship's threat. Santos only could establish himself as a full professor at USP in 1983 (Contel 2011, 399; Silva 2011, 68).

In Brazil, Santos continued his collaboration with the 'Northern' geographers he was acquainted with, including Smith, Slater and especially Peet. Together with Peet, Santos was the editor of a series of three projected special issues of Antipode, the first one published in February 1977, with a preface co-signed by Peet and Santos, and the second published in September 1977, with a preface by Slater. The editors of these issues were committed to involve authors from the South, as Santos did during his stay in Tanzania, during which time he worked closely with Slater for the preparation of the first issue. ${ }^{5}$ In a letter, dated June 1976, Professor V.C. Mulchansingh from the University of the West Indies in Kingston submitted to Santos a paper titled 'Spatial aspects of dependency a prolegomenon to total planning', which was apparently not published, while in September of the same year, Nigerian sociologist Akinsola Akiwowo asked for a copy of the special issue. ${ }^{6}$ Another Nigerian scholar, the environmental scientist Joseph Theophilus Uyanga, then lecturer at the University of Calabar, offered a paper on 'Perspectives on national growth and regional

${ }^{4}$ IEB, MS-EO006-038-02 [Santos' notes]. All quotes from sources in French, Spanish and Portuguese have been translated by the authors.

${ }^{5}$ R. Peet, Interview with the authors, 25 April 2017.

${ }^{6}$ IEB, MS-RS76-008, Akiwowo to Santos, 27 September 1976.

Federico Ferretti \& Breno Viotto Pedrosa, 2018, "Inventing critical development: a Brazilian geographer and his Northern networks", Transactions of the Institute of British Geographers [early view https://onlinelibrary.wiley.com/doi/full/10.1111/tran.12241 ] 
development in Nigeria 1960-70'. The enclosed notes from Peet, asking Santos if he was willing to include this paper in one of the issues, show the role played by Santos in editing these issues, which inaugurated a systematic interest on the part of Anglophone radical geographers in matters of underdevelopment. ${ }^{7}$ In the same year, a letter from the Argentinian economist Javier Lindenboim, member of the Inter-American Society of Planning, acknowledged Santos for encouraging him to seek the authorization for republishing Antipode materials in Buenos Aires. ${ }^{8}$ Santos committed to what today is called 'global engagement', networking with scholars of different continents and linguistic areas with the aim of stimulating interest on underdevelopment, by editing issues of the major radical scholarly journals in France and in North America and by promoting their circulation and translation in Southern countries.

The two Antipode issues finally published in 1977, of the three initially envisaged (as the third was never realised), help us to appreciate the terms and nature of Santos and Peet's project. In their introduction, the two geographers wrote that their first aim was to give voice to scholars from the South, a fact 'rather unusual in the Anglo-Saxon world where debates about poor countries have been for long a de facto monopoly of western scholars' (Santos and Peet 1977, 1). The main theoretical contribution from outside Anglo-Saxon scholarship, considered to 'come mainly from Italy, France and Latin America' (1977, 1) was the introduction of the concepts of mode of production and especially of Socio-Economic Formation (SEF), accompanied by an implicit critique of mainstream geographers, as these two concepts 'have been utterly neglected in spatial studies' $(1977,2)$. On the other hand, non-geographical Marxists were likewise criticized, as they 'have been mistaken when working on this category without considering space ... one must speak of socio-economic spatial formation, since the SEF could not exist out of space and since society is objectified through geographical forms' $(1977,2)$.

The first of Santos' papers in this issue (Santos 1977a) is considered a classical piece in his interpretation of SEF. Santos called for a general theory of society and space, challenging

${ }^{7}$ IEB, MS-RS76-007, Uyanga to Santos, 23 December 1976.

${ }^{8}$ IEB, MS-RS76-018, Lindenboim to Santos, 16 July 1976.

Federico Ferretti \& Breno Viotto Pedrosa, 2018, "Inventing critical development: a Brazilian geographer and his Northern networks", Transactions of the Institute of British Geographers [early view https://onlinelibrary.wiley.com/doi/full/10.1111/tran.12241 ] 
conservative traditions in geography which he deemed 'more interested in the form of things than in their formation' (1977a, 3). His definitions of SEF recalled the idea that geographical and historical approaches should be strictly interconnected, which characterised the tradition of French geography discussed by Santos in his work on the history of geography (Santos 1985). For Santos, 'modes of production write history in time; social formations write it in space' (Santos 1977a, 5). Being 'form-contents', SEFs overtook economic readings of reality, as they constitute what the Italian philosopher Antonio Labriola defined as 'an organic conception of history. This concept encompasses the totality of the unity of social life' (1977a, 7), in which space 'becomes a fundamental component of the social totality and its movements' (1977a, 7). Santos expressed a dialectics between structure and agency, in the sense of his pragmatism, rejecting both determinism and fixed theoretical models in order to adapt different solutions to different geographical realities.

In the same Antipode issue, one finds the article 'Social forms of space organization and their trends in Latin America', written by Argentinian economist José Coraggio, then based in Mexico. One of the main critics of the growth poles' theory, Coraggio introduced in this work the idea of the 'unequal development in space' (Coraggio 1977, 25) of productive forms. In their paper published in the same issue, 'Modernization and social protest movements', Alasdair Drysdale and Michael Watts questioned the "shortcoming and ethnocentrism of the "geography of modernisation"" (Drysdale and Watts 1977, 40), anticipating critiques of modernity as an ideology and highlighting the importance of indigenous movements in the Global South. Other papers were authored by, among others, Anouar Abdel-Malek, of Paris CNRS; Sonia Barros of the Central University of Venezuela; Bashir A. Datoo of the University of Dar es Salaam; Alejandro Forman and Ruiz Alberto Romero of the Di Tella Institute in Buenos Aires; and Angel Batalla of the Autonomous National University of Mexico, showing the effort to involve different continents and linguistic areas in the exchange.

The second issue of this series, published in December 1977 and corresponding to the third Antipode issue of the year, also brought together Southern and Northern scholars. It was introduced by David Slater, who echoed Santos' critical views of development geography, which have 'tended

Federico Ferretti \& Breno Viotto Pedrosa, 2018, "Inventing critical development: a Brazilian geographer and his Northern networks", Transactions of the Institute of British Geographers [early view https://onlinelibrary.wiley.com/doi/full/10.1111/tran.12241 ] 
to act as a conveyor-belt for theories produced in other more dominant segments of orthodox social science' (Slater 1977, 1). Instead he argued for a geography that challenges 'the assumed equivalence of economic growth and development' $(1977,2)$; unfinished business according to the most recent work of these critical scholars (Peet and Hartwick 2015). Santos contributed two papers to this issue: 'The two circuits of urban economy in underdeveloped countries', which explained the theory of the shared space (Santos 1977b), and the second that criticized the politics of planning implemented in poor countries. As recently demonstrated by Brazilian scholarship (Pedrosa 2013), this critique did not imply Santos' lack of interest in planning issues. On the contrary, the paper demonstrated his commitment to them, by acknowledging the importance, for Santos' project of an active and engaged geography, 'of the role played by planning. It is not even necessary to qualify it as capitalistic planning for underdeveloped countries have known nothing else' (Santos 1977c, 86). Santos also criticized the ideology of growth and the creation of needs, also including the 1949 speech of President Truman discussed above, which later became one of the favourite targets for anti-development scholarship. For Santos, what Truman deemed 'aid' was 'nothing else than a form, insufficiently concealed, of the conquest of poor countries by capital; it is a vehicle of domination' (1977c, 87). Likewise, Santos criticized the core-periphery model by John Friedmann and the theory of growth poles in Latin America, which 'served the diffusion of capital in space' (1977c, 89). A paper by Yves Lacoste concluded the issue. The weight and importance of Santos' contribution is confirmed by Peet, who argues that Santos' notion of 'Socio-spatial formation was a major idea in debates about modes of production in the 1970s and 80s', and that 'the two issues were the best we had published up to that point ${ }^{,},{ }^{9}$ which suggests that Santos was a protagonist in efforts to interest international geographical scholarship in Third World issues.

A collection of 1977-78 letters in the Santos archives demonstrates the extent of Peet and Santos' collaboration in preparing the Antipode special issues and in disseminating them, as well as in networking in what is now called the Global South. In March 1977, Santos announced the reception of new abonnements to Antipode from 'Third World' countries, and requested more copies for free

\footnotetext{
${ }^{9}$ R. Peet, Interview with the authors, 25 April 2017.
}

Federico Ferretti \& Breno Viotto Pedrosa, 2018, "Inventing critical development: a Brazilian geographer and his Northern networks", Transactions of the Institute of British Geographers [early view https://onlinelibrary.wiley.com/doi/full/10.1111/tran.12241 ] 
distribution and advertisement, suggesting that each author receive 20 copies of the journal. ${ }^{10}$ In October, Peet wrote that he had sent 5 copies to Coraggio and 20 to Maza Zavala and that he was starting work in further issues on underdevelopment. Peet also announced the publication of his book Radical geography (1978), which collected together the texts of Lacoste, Henri Lefebvre, Doreen Massey, Bunge, Harvey, Slater, Buchanan, Jim Blaut and the 'founding fathers' of the tradition, Reclus and Kropotkin. ${ }^{11}$ This book attempted to bridge French-speaking and Englishspeaking critical traditions. It was published while Santos was editing the Antipode's special issues on underdevelopment, which the Brazilian geographer considered as part of his strategy for a world projection of critical and radical geographies. It was Santos' intention that the 'Third World' was not so much an area of expansion, but was to be a key player in these developments. That said, Santos' project was not devoid of problems and contradictions and had to stop, as we explain below.

The letters surviving in the IEB show that after the first special issue, the program for the publication of papers on underdevelopment was reduced due to Peet's dissatisfaction with the quality of the texts received. Concerning the papers in the issue he was preparing with Philip O'Keefe, Peet wrote to Santos to say that 'Our decision is to reject about half of them and to combine the remaining papers in one issue of Antipode (vol. 9, $\mathrm{n}^{\circ} 3$, December, 1977) '. ${ }^{12}$ His letters to Peet reveal Santos' disappointment in his Northern colleagues. 'I believed you would publish two [more] issues of Antipode. As you know, I have been in touch with a lot of people since 1974, and they have been waiting since then for the publication.... I even don't know the criteria that prevailed in the selection. The issue will include too few papers from Third World scholars, which is just the country of my original intention'. ${ }^{13}$ Santos lamented the impossibility to continue his ambitious programme and the fact that Peet seemed to value more academic respectability than their original project of giving voice to intellectuals from the South. Yet, this did not interrupt his

\footnotetext{
10 IEB, MS-RS77-014, Santos to Peet, 14 March 1977.

${ }^{11}$ IEB, MS-RS77-014, Peet to Santos, 3 October 1977.

12 IEB, MS-RS77-014, Peet to Santos, 9 December 1977.

13 IEB, MS-RS77-014, Santos to Peet, 27 February 1978.
}

Federico Ferretti \& Breno Viotto Pedrosa, 2018, "Inventing critical development: a Brazilian geographer and his Northern networks", Transactions of the Institute of British Geographers [early view https://onlinelibrary.wiley.com/doi/full/10.1111/tran.12241] 
collaboration with Antipode and with Peet, who answered explaining his reasons on the bases of editorial issues and papers' quality, hoping that what happened 'does not harm our friendship which is important to me'. ${ }^{14}$ The fact that Peet asked Santos about the academic affiliations of several authors indicates that Santos was the connection between them and Antipode, showing again the importance of the role played by the Brazilian geographer in the international networking for what was then defined 'radical geography'. If this role is paramount in understanding Santos, his disappointment revealed the limits of his challenges and the fact that getting rid of Euro-centrism was manifestly unfinished business in radical scholarship.

In February 1978, Santos asked Peet for advice about editing in Brazil a Critical Geography Reader, which would collect together papers published in journals such as Progress in Human Geography and the Annals of the Association of American Geographers between 1975 and 1978, to be translated in Portuguese and published before the 1978 Fortaleza conference mentioned above. It is worth noting that this conference was a watershed in the affirmation of critical geography in Brazil (Borzacchiello 2016), as it challenged both the dictatorship and the academic establishment, including the quantitative geography mostly practiced in centres such as the Brazilian Institute of Geography and Statistic (Pedrosa 2013). The shift towards qualitative methods and critical approaches opened a new period for Brazilian geography and Santos' return played a strong symbolic role (Moreira 2000). In March 1978, Santos wrote to Slater, then at the University of Amsterdam, to ask his authorisation for publishing a Portuguese version of Slater's text The poverty of modern geographical enquiry (1975) in the aforementioned Reader, confiding to Slater his difficult acclimation to São Paulo and arguing that: 'It is time to introduce a new drive in our discipline which is knowing now a kind of renovation.' ${ }^{15}$ Since that moment, Santos' efforts were directed mainly towards Brazilian geography, because the prestige he acquired with his international experiences boosted his local success, allowing him to introduce new contents in the discipline (Grimm 2011, 177). Brazilian geography proved to be fertile terrain for Santos' 'new drive', that is the spread of critical and radical tendencies in geography.

\footnotetext{
${ }^{14}$ IEB, MS-RS77-014, Peet to Santos, 16 March 1978.

15 IEB, MS-RS78-029, Santos to Slater, 6 March 1978.
}

Federico Ferretti \& Breno Viotto Pedrosa, 2018, "Inventing critical development: a Brazilian geographer and his Northern networks", Transactions of the Institute of British Geographers [early view https://onlinelibrary.wiley.com/doi/full/10.1111/tran.12241 ] 
In the same year, 1978, Santos corresponded with Neil Smith (1954-2012), another protagonist of these debates, one whose work has also been reappraised in the last few years (Mitchell 2014). The letters surviving at IEB start in June 1978 when Smith invited Santos to contribute to a project of the Union of Socialist Geographers called Uneven development and environment. The aim of the book was to challenge 'orthodox geography' in order to seek 'alternative models' ${ }^{16}$ In Smith's definition, this book was to be an 'Anti-Haggett', referencing Engels's Anti-Düring and targeting the figure of Peter Haggett, who was considered to represent quantitative geography more generally. Smith attached a copy of the book project, to be divided in four parts. 'I) Materialism and geography - 1) Historical materialism; 2) Geography as ideology and technology; 3) Definitions: development, environment, location; II) Uneven development - 4) Critique of development models; 5) Imperialism; 6) Regional underdevelopment; 7) Urban capital and spatial patterns; III) Environment - 8) Critique of ecology models, determinism; 9) Resources as commodities; 10) Population and class; 11) Hazards; 12) Culture and perception; IV) Geography and socialism - 13) Socialism and environment'. ${ }^{17}$ From the following letter from Smith, dated October 1978, it is possible to infer that Santos expressed interest in the project. He was then asked to send a contribution at his discretion for the part 'Concepts: development, environment, location'. ${ }^{18}$ Smith enquired about the state of Santos' research, and when told he was working on gentrification, asked Santos to read and comment before publication a text, 'Gentrification and capital', which Smith finally published in Antipode the following year. In a later interview on his relationship with Santos, Smith recounted to Maria Adélia Aparecida de Souza how he was impressed by Santos' international networks (Souza 1996, 188). The correspondences between Santos and Smith reveal Santos' collaboration with another international exponent of so-called 'radical geography', and accordingly his role of senior advisor for some of Smith's early works.

\footnotetext{
${ }^{16}$ IEB, MS-RS78-054,Smith to Santos, 21 June 1978.

${ }^{17}$ IEB, MS-RS78-054, USG Textbook on Geography and Socialism, 21 June 1978.

${ }^{18}$ IEB, MS-RS78-055, Smith to Santos, 7 September 1978.
}

Federico Ferretti \& Breno Viotto Pedrosa, 2018, "Inventing critical development: a Brazilian geographer and his Northern networks", Transactions of the Institute of British Geographers [early view https://onlinelibrary.wiley.com/doi/full/10.1111/tran.12241] 


\subsection{French controversies}

Santos made an important contribution to international scholarship through his original reading of the history of French geography, recovering critically certain scientific tools of the Vidal de la Blache's school. From French geography, Santos especially took the idea of 'unity of the real world' (Bernardes et al. 2017, 4), to build a comprehensive geography serving social transformation (Melgaço 2007). In the long tradition of French-Brazilian exchanges in geography, a scholar whom Santos considered as one of his masters, Josué de Castro (1908-1973), was also one of the first South-American authors who quoted Elisée Reclus in order to apply his ideas to the social problems of Brazil in the 1930s. One of de Castro's (1937) first essays on geography and alimentation inspired the work of French social geographer Max Sorre (1943), who then mentioned de Castro's books Geografia da Fome (Geography of Hunger) and Geopolitica da Fome (Geopolitics of Hunger) as fundamental resources (Sorre 1952) for a geography of food. On the one hand, de Castro owed something to European authors such as Reclus, as he relied 'on Reclus's New Universal Geography to talk about universal hunger' (Teles de Carvalho 2009, 85) and considered the French anarchist geographer as the only European scientist who did not hide the famines that affected countries such as India at the end of the nineteenth century (De Castro 1952, 27). On the other, we can see in his case an example of the lack of acknowledgement, or even paternalism, which characterized the consideration of these Southern scholars in Europe. It is the case of Sorre who, in his introduction to the French edition of the Geography of Hunger, acknowledged it as 'the first chapter of every human geography' (De Castro 1952, 9) but also claimed the primacy of French geography through generic mentions of Reclus and Vidal de la Blache. Nevertheless, in the 1950s, Reclus himself was almost completely forgotten by French geographers and Sorre seems to quote him in a clumsy patriotic attempt to keep French geography at the centre of the stage, only because de Castro reminds him of the existence of this figure.

Santos likewise contributed to the 'rediscovery' of anarchist geographers Reclus and Kropotkin, quoting them in Por uma geografia nova/Pour une géographie nouvelle (For a new geography). According to Santos, if on the one side stood imperial geography, 'on the other side we find those who struggled for a more even world where space will be organized with the aim to give humans

Federico Ferretti \& Breno Viotto Pedrosa, 2018, "Inventing critical development: a Brazilian geographer and his Northern networks", Transactions of the Institute of British Geographers [early view https://onlinelibrary.wiley.com/doi/full/10.1111/tran.12241] 
more equality and happiness: they are the cases of Elisée Reclus and Camille Vallaux. Can we include Kropotkin among those who saw in space one of the keys to build a new society? Yes, and never mind if the Anarchist Prince was not officially a geographer' (Santos 1984(1978), 20). Actually, Kropotkin was a geographer (Ferretti 2011; Kearns 2009), but only later was this widely acknowledged by new 'radical' geographies. Santos' archives confirm that he was a reader of Kropotkin, and that in his notes he addressed Kropotkin's urban writings, noting: 'Will the capitalist city survive? The Engels' despair and the Kropotkin's hope'. ${ }^{19}$ Brazilian scholarship suggests that there were similarities between Santos' ideas and the works of authors sharing many of Reclus's and Kropotkin's views on urban matters, such as Patrick Geddes and Ebenezer Howard, especially around the notion of solidarity, 'not based on the moral aspect, but on the coexistence [of social groups in space] by necessity of mutual protection' (Pozzer et al. 2011, 59). If this recalls Kropotkin's concept of mutual aid, Kropotkin's books, including Mutual aid, Fields factories and workshops and selected works in Spanish and Portuguese, were part of Santos' personal library, also including Reclus's classics such as L'Homme et la Terre. ${ }^{20}$

After his return to Brazil, Santos continued his correspondence and collaborations with French geographers. In February 1978, Jacqueline Beaujeu-Garnier wrote in a very friendly tone encouraging Milton to settle again in Bahia, suggesting that he would be more comfortable there than in São Paulo. ${ }^{21}$ In the same year, Bernard Kayser wrote to Santos to discuss their respective papers in issue 8 of Hérodote, politely criticizing some points of Santos' paper 'From society to landscape'. According to Kayser, Santos presented a vision of landscape and its perception that was not 'naturalistic' enough. ${ }^{22}$ Kayser's letters continued to reach Santos to discuss personal and family issues and to plan a common trip to Salvador and Recife. ${ }^{23}$

\footnotetext{
${ }^{19}$ IEB, MS-EO007-005-12, Caixa 022 - 'Cidade como máquina. Economia urbana da cidade'.

${ }^{20} \mathrm{IEB}$, General Inventory, http://200.144.255.59/catalogo_eletronico/consultaDocumentos.asp

${ }^{21}$ IEB, MS-RS78-053, Beaujeu-Garnier to Santos, 9 January 1978.

22 IEB, MS-RS78-067, Kayser to Santos, 22 February 1978.

${ }^{23}$ IEB, MS-RS78-069, Kayser to Santos, 29 November 1978; IEB, MS-RS78-068, Kayser to Santos [no date].
}

Federico Ferretti \& Breno Viotto Pedrosa, 2018, "Inventing critical development: a Brazilian geographer and his Northern networks", Transactions of the Institute of British Geographers [early view https://onlinelibrary.wiley.com/doi/full/10.1111/tran.12241 ] 
The most interesting part of Santos' relations with French geographers after his return to Brazil in 1977 concerns a poorly defined controversy with Yves Lacoste, editor of Hérodote, a journal founded in 1976 which was for many years the main reference of radical geography in Frenchspeaking countries. In his recollections, Santos asserted his role in developing Hérodote, pointing to the lack of acknowledgement by Lacoste, which the Brazilian geographer attributed to Lacoste's progressive estrangement from Marxism. 'Since the beginning of the 1970s, what can I possibly say, I helped to fund Hérodote together with Yves Lacoste, who later began to say that he was not Marxist' (Buss et al. 1991, 140). Under Lacoste's leadership, Hérodote gradually turned away from the radicalism of the 1970s towards more moderate positions which, according to Les Hepple, also meant some ‘depoliticization' (Hepple 2000, 290) and highlighted problematic aspects of Lacoste's thinking, such as French nationalism. Critical geographer Claude Raffestin 'has attacked what he sees the reactionary emphasis of nation and nationalism in Hérodote' $(2000,291)$.

If Santos' remarks on Lacoste revealed his final dissatisfaction with Hérodote, an explicit complaint was addressed by Santos to Lacoste in 1980. The Brazilian geographer requested the correction and re-publication of what he defined a 'disastrous' 24 interview that appeared in issue 17 of Hérodote, whose rough draft was published, without Santos' approval, instead of the definitive version he said he had sent. To our best knowledge, no correction was published and no answer from Lacoste survives in Santos' archives. If Santos' version of events is correct, this episode might substantiate the suspects of those Third World intellectuals who lamented a certain 'haughtiness' of some Northern scholars towards Southern ones. In Santos' archives, this was accordingly the case with his Argentinian correspondent Néstor Miguel Gorojovski, the representative of the radical geographic association Espacio Libre (Free Space), who complained because, after sending several letters, he was still waiting for a response from Italian Marxist geographer Massimo Quaini. ${ }^{25}$ However, Santos' correspondence demonstrates that he continued his exchanges with French friends such as Rochefort ${ }^{26}$ and the elderly Pierre George, ${ }^{27}$ who both

\footnotetext{
${ }^{24}$ IEB, MS-RS80-014, Santos to Lacoste, 29 February 1980.

${ }^{25}$ IEB, MS-RS85-077, Gorojovsky to Santos, 3 October 1985.

${ }^{26}$ IEB, MS-RS85-099, Rochefort to Santos, 22 October 1985.

${ }^{27}$ IEB, MS-RS85-028-B, George to Santos 23 October 1985.
}

Federico Ferretti \& Breno Viotto Pedrosa, 2018, "Inventing critical development: a Brazilian geographer and his Northern networks", Transactions of the Institute of British Geographers [early view https://onlinelibrary.wiley.com/doi/full/10.1111/tran.12241] 
endorsed his book Pour une géographie nouvelle. Other correspondences and notes surviving at IEB concern Santos' project to edit volumes on the French geographers 'Bernard Kayser, Yves Lacoste and Jean Dresch' for a series titled 'Great Social Scientists' ${ }^{28}$ supervised by the radical Brazilian sociologist Florestan Fernandes.

This section has shown that, on the one hand, the South was not a mere receptor of ideas borrowed from the North. On the other, geographers like Santos and de Castro worked with European and North American scholars, while other Southern scholars seem to have been marginalized. This raises the problems of inclusion and pluralism still debated in geographical scholarship (Esson et al. 2017), and demonstrates that claiming critical and radical approaches is not automatically a guarantee of avoiding prejudices and Euro-centrism.

\section{Conclusion: not dependents in theory}

Through the exploration of primary sources, we have shown how important some scholars from the Global South were to critical and radical geographical scholarship in the second half of the twentieth century, particularly in relation to matters of poverty and 'underdevelopment'. First, this paper progresses geographical debates about development theories by demonstrating that by the 1970s geographers from the Third World were willing to go beyond developmentalism to a point where they provided insights for contemporary ideas on democratic development and critical modernity (Peet and Hartwick 2015). By anticipating later criticisms of the ideology of development', scholars such as Santos furnished key insights into the grand 'convergence' in the field of development studies then recommended by geographers such as Power, Sidaway and Simon. Their reconsideration contributes also to what Björn Hettne called the 'need for self-critical theories' (Hettne 2008, 10) in this field. Yet, Santos' disappointment with some of his Northern collaborators exemplifies a lack of acknowledgement for these contributions.

${ }^{28}$ IEB, MS-RS83-040, Santos to Fernandes, 21 May 1983.

Federico Ferretti \& Breno Viotto Pedrosa, 2018, "Inventing critical development: a Brazilian geographer and his Northern networks", Transactions of the Institute of British Geographers [early view https://onlinelibrary.wiley.com/doi/full/10.1111/tran.12241 ] 
Second, this paper participates in recent and ongoing efforts to bring Santos' works, and also broader critical Brazilian scholarship, to the attention of English-speaking publics, showing how the contributions of Santos and other Southern scholars remain to a large extent underplayed in international scholarly literature. It is worth noting that Peet agrees on this point in his interview with us. ${ }^{29}$ Today, as the materials recently published by Antipode show, Santos' work 'asks fundamental questions that are of interest to scholars worldwide' (Melgaço 2017, 3) such as an ecumenic concept of the geographical space as 'the space of all humankind, regardless of its differences' (Bernardes et al. 2017, 2). These ideas can advance present-day debates in geography, setting out important elements of reflection such as Santos' cosmopolitism, multilingualism and commitment to working in militant situations beyond academia. Santos is still an influential author in Latin America and especially in Brazil, where he is considered as an unchallenged authority (Grimm 2011) and where his main works are often quoted as gospel but not always critically discussed and contextualised. Therefore, further work is needed on primary sources related to Santos and other Brazilian and Latin American radical geographers to advance research on their works and networks and to foster intercultural dialogue between critical scholars from the Global North and the Global South.

Third, this paper offers a twofold contribution to current understanding of the history of geography. On the one hand, it demonstrates the effectiveness of analysing scholarly networks through the study of unpublished correspondences in order to put the geographical discipline and its protagonists in their social and intellectual contexts. Santos' biographic trajectory needs to be understood not simply in its geographical situatedness, but more broadly in its plurality of places and in Santos' mobilities: addressing Santos' life and work through the contexts of his international scholarly networks demonstrates his contribution to the shaping of radical geographies. On the other, this paper shows the importance of reconsidering geographical traditions which can be deemed alternative to conservative scholarship and to the cultural domination of European and North-American models in the field of critical and radical geographies. Drawing upon Melgaço's

${ }^{29}$ R. Peet, Interview with the authors, 25 April 2017.

Federico Ferretti \& Breno Viotto Pedrosa, 2018, "Inventing critical development: a Brazilian geographer and his Northern networks", Transactions of the Institute of British Geographers [early view https://onlinelibrary.wiley.com/doi/full/10.1111/tran.12241] 
and Prouse's arguments evoking decolonial ideas and defining Santos as a 'border thinker' (Melgaço and Prouse 2017, 6), we would like to conclude by arguing that more work on these alternative geographical traditions can serve wider agendas for decolonizing academia.

\section{Acknowledgements}

This research was supported by the UCD College of Social Sciences and Law Research with Grant RS15975, and by the Royal Irish Academy with the 2017 Charlemont Travel Grant. Special thanks to Richard Peet, who had the kindness of conceding us an interview. We are also thankful to the São Paulo IEB officers, and especially to Denise and Bete, for their kindest and very helpful support. Likewise, we acknowledge the 'Miltonian' colleagues at USP for their suggestions, in particular Flávia Grimm, Maria Adelia Aparecida de Souza and Fábio Contel. Great thanks also to Alun Jones for his rereading, to David Simon, Marcus Power and James Sidaway for their feedback on the initial idea of this project, to the three anonymous referees for TIBG and to the editor, Simon Naylor, for their useful suggestions and remarks.

\section{Bibliography}

Ashmore P, Craggs R and Neate H 2012 Working-with: talking and sorting in personal archives Journal of Historical Geography 38 81-89.

Barnes T 2001 Lives lived and lives told: biographies of geography's quantitative revolution Environment and Planning D: Society and Space 19 409-429.

Bernardes A et al. 2017 The active role of geography: a manifesto Antipode http://onlinelibrary.wiley.com/doi/10.1111/anti.12318/full DOI: 10.1111 [Early View].

Blomström M and Hettne B 1984 Development theory in transition: the dependency debate and beyond: third world responses Zed Books, London.

Bomfim P A and Vargar H M 2014 La geografía latinoamericana y la Unión Geográfica Internacional (UGI): los casos de Brasil (1956) y México (1966) Journal of Latin American Geography 13 215-232.

Bomfim, P A 2015 Michel Rochefort e o Instituto Brasileiro de Geografia e Estatística na década de 1960 in Sociedade e Natureza 27 365-378.

Federico Ferretti \& Breno Viotto Pedrosa, 2018, "Inventing critical development: a Brazilian geographer and his Northern networks", Transactions of the Institute of British Geographers [early view https://onlinelibrary.wiley.com/doi/full/10.1111/tran.12241 ] 
Borzacchiello da Silva J 2016 French-Brazilian geography: the influence of French geography in Brazil Springer, Berlin.

Bowd G and Clayton G 2005, French tropical geographies: Editors' introduction Singapore Journal of Tropical Geography, 26, 271-288.

Buchanan K 1977 Reflections on a dirty word in Peet R ed Radical Geography Methuen London 363-377.

Buss M D Mamigonian A Machado V. V and Pereira M F A 1991 Entrevista com o professor Milton Santos Geosul 6 170-201.

Cirqueira D M 2010, A questão negra na trajetória teórica do geógrafo Milton Santos in Anais do XVI Encontro Nacional dos Geógrafos AGB, Porto Alegre 1-11.

Claval P 2005 Colonial experience and the development of tropical geography in France Singapore Journal of Tropical Geography 26 289-303.

Contel F B 2014 Milton Santos in Secco L and Pericas L B eds. Intérpretes do Brasil. Boitempo, São Paulo 393-409.

Coraggio J L 1977 Social forms of space organization and their trends in Latin America Antipode 9 14-27.

Corbridge S 1984 Capitalist world development, a critique of radical development geography Rowman and Littlefield, Totowa.

De Castro J 1949 Géographie de la faim [Geografía da fome] Les éditions ouvrières, Paris.

De Castro J 1952 Géopolitique de la faim [Geopolítica da fome] Les éditions ouvrières, Paris.

Delgado de Carvalho C M 1910 Le Brésil méridional : étude économique sur les États du Sud. Imprimerie Desfossés, Paris.

Dodds K 2008 The Third World, developing countries, the South, poor countries in Desai V and Potter $\mathbf{R}$ The companion to development studies Hodder, London 3-7.

Dresch J 1979 Un géographe au déclin des empires Maspero, Paris.

Dresch J Lacoste Y Pinchemel P Monbeig P and Moral P eds 1967 Dossier Géographie et développement Annales de Géographie 418 641-767.

Driver F and Yeoh B 2000 Constructing the Tropics: Introduction Singapore Journal of Tropical Geography 21 1-5.

Federico Ferretti \& Breno Viotto Pedrosa, 2018, "Inventing critical development: a Brazilian geographer and his Northern networks", Transactions of the Institute of British Geographers [early view https://onlinelibrary.wiley.com/doi/full/10.1111/tran.12241] 
Drysdale A and Watts M 1977 Modernization and social protest movements Antipode 9 40-55.

Dussel E Krauel J Tuma V 2000 eds. Europe, Modernity, and Eurocentrism Nepantla, views from South 1.

Escobar A 1995 Encountering development, the making and unmaking of the Third World Princeton University Press, Princeton.

Esson J, Noxolo P, Baxter R., Daley P and Byron M 2017 The 2017 RGS-IBG chair's theme: decolonising geographical knowledges, or reproducing coloniality? Area 49(3) 384-388.

Esteva G 1992 Development in Sachs W ed. The Development Dictionary, a guide to knowledge as power Zed Books, London 6-25.

Ferretti F 2011 The correspondence between Élisée Reclus and Pëtr Kropotkin as a source for the history of geography Journal of Historical Geography 37 216-222.

Ferretti F 2014 Pierre Deffontaines et les missions universitaires françaises au Brésil: enjeux politiques et pédagogiques d'une société savante outremer (1934-1938) Cybergeo http://cybergeo.revues.org/

Finn JC and Hanson AM 2017, Critical geographies in Latin America, Journal of Latin American Geography 16, 1-15.

Gore C 1984 Regions in question. Space, development theory and regional policy London and New York, Methuen.

Grimm Andrade F 2011 Aspectos da produção teórica e da organização do arquivo de documentos do geógrafo Milton Santos Revista do Instituto de Estudos Brasileiros 52 165-182.

Harvey D 2006 Spaces of Global capitalism: towards a theory of uneven geographical development Verso, London.

Hepple L 2000, Yves Lacoste, Hérodote and French radical geopolitics in Dodds K and Atkinson D Geopolitical Traditions Routledge, London, 268-301.

Hettne B 2008 Current trends and future options in development studies in Desai V and Potter R The companion to development studies Hodder, London 8-11.

Kay C 1989 Latin American theories of development and underdevelopment London and New York, Routledge.

Federico Ferretti \& Breno Viotto Pedrosa, 2018, "Inventing critical development: a Brazilian geographer and his Northern networks", Transactions of the Institute of British Geographers [early view https://onlinelibrary.wiley.com/doi/full/10.1111/tran.12241] 
Kearns G 2009 Geopolitics and Empire, the legacy of Halford Mackinder Oxford University Press, Oxford.

Keighren I 2012 Fieldwork in the archive in Phillips R and Johns J Fieldwork for human geography SAGE, London 138-40

Lacoste Y 1962 Le sous-développement: quelques ouvrages significatifs parus depuis dix ans Annales de Géographie 71(386) 387-414.

Lévy J 2007 ed. Milton Santos: philosophe du mondial, citoyen du local Presses Polytechniques et Universitaires Romandes, Lausanne.

Mamigonian A 2004 Milton Santos: a formação de um pensador universitário crítico in Brandão M A ed. Milton Santos e o Brasil Editora Fundação Perseu Abramo, São Paulo.

Melgaço L 2017 Thinking outside the bubble of the Global North: introducing Milton Santos and "the active role of geography" Antipode http://onlinelibrary.wiley.com/doi/10.1111/anti.12319/full DOI: 10.1111/anti.12319 [Early View]

Melgaço L and Prouse C 2017 ed. Milton Santos: Pioneer in Geography Springer, London.

Mignolo W 2011 The darker side of Western modernity: global futures, decolonial options Duke University Press, Durham.

Mitchell D 2014 Neil Smith, 1954-2012: Marxist geographer Annals of the Association of American Geographers 104 215-222.

Moral P 1967 Aspects régionaux du sous-développement. Essai de comparaison entre l'Afrique de l'Ouest et l'Amérique Latine Annales de Géographie 76(418) 681-703.

Moreira R 2000 A Renovação da Geografia Brasileira no Período 1978-1988 Geographia 3 2749.

Orain 02009 De plain-pied dans le monde L'Harmattan, Paris.

Pedrosa B V 2013 Entre as ruínas do muro: a história da geografia crítica sob a ótica da ideia de estrutura $\mathrm{PhD}$ Dissertation, São Paulo.

Peet R and Hartwick R 2015 Theories of development The Guilford Press, London.

Peet R and Watts M 1996 eds. Liberation ecologies, environment, development, social movements Routledge, London and New York.

Federico Ferretti \& Breno Viotto Pedrosa, 2018, "Inventing critical development: a Brazilian geographer and his Northern networks", Transactions of the Institute of British Geographers [early view https://onlinelibrary.wiley.com/doi/full/10.1111/tran.12241] 
Pinchemel P Robic M C and Tissier J L 2011 eds Deux siècles de géographie française: une anthologie CTHS, Paris.

Power M 2003 Rethinking development geographies Routledge, London.

Power M and Sidaway J D 2004 The degeneration of tropical geography Annals of the Association of American Geographers 94 585-601.

Pozzer C Leite E Albuquerque D Argollo Ferrão A and S. Fuad Gattaz 2011 Thinking about regional planning based on the studies of Ebenezer Howard, Patrick Geddes and Milton Santos Journal of Integrated Design \& Process Science 15 57-61.

Raghuram P Madge C 2006 Towards a method for postcolonial development geography? Possibilities and challenges Singapore Journal of Tropical Geography 27 270-288.

Santos M 1967 L'alimentation des populations urbaines de pays sous-développés Tiers monde 8 605-629.

Santos M 1969 Aspects de la géographie et de l'économie urbaines des pays sous-développé Centre de Documentation Universitaire, Paris.

Santos M 1970 Dix essais sur les villes des pays sous-développés Éditions Ophrys, Paris.

Santos M 1971 Le Métier de géographe en pays sous-développé, un essai méthodologique Éditions Ophrys, Paris.

Santos M 1977a Society and space: social formation as theory and method Antipode, 9, $13-13$.

Santos M 1977b, Spatial dialectics: the two circuits of urban economy in underdeveloped countries, Antipode, 9, 3 49-60.

Santos M 1977c, Planning underdevelopment, Antipode, 9, 3 86-98.

Santos M 1978 Rêve et cauchemar: problèmes spatiaux de la transition au socialisme. Le cas de la Tanzanie Tiers Monde 19 563-572.

Santos M 1979 The shared space: the two circuits of the urban economy in underdeveloped countries Methuen, London [L'espace partagé Génin, Paris 1975 - O espaço dividido EDUSP, São Paulo 2004].

Santos M 1985 Pour une Géographie nouvelle Publisud, Paris [Por uma geografia nova, Ucitec, São Paulo 1978].

Federico Ferretti \& Breno Viotto Pedrosa, 2018, "Inventing critical development: a Brazilian geographer and his Northern networks", Transactions of the Institute of British Geographers [early view https://onlinelibrary.wiley.com/doi/full/10.1111/tran.12241] 
$\begin{array}{lllll}\text { Santos } & \text { M } & 2001 & \text { Curriculum }\end{array}$ http://www.miltonsantos.com.br/site/miltonsantos_curriculum.pdf.

Santos M and Peet R 1977 Introduction in Santos M and Peet R eds. Underdevelopment in the Third world Antipode special issue, 1-3.

Santos M 2002 Ser negro no Brasil hoje in Ribeiro W C ed. O país distorcido: o Brasil, a globalização e a cidadania Publifolha, São Paulo 157-161.

Schuurman F 2008 The impasse in development studies in Desai V and Potter R The companion to development studies Hodder, London 12-15.

Sidaway J D 2007 Spaces of Postdevelopment Progress in Human Geography 31 345-361.

Sidaway J D 2008 Post-development, in Desai V and Potter R The companion to development studies Hodder, London 16-19.

Silva M A 201110 anos sem Milton Santos ALBA, Salvador.

Simon D 1997 Development reconsidered: new directions in development thinking Geografiska Annaler 79 183-201.

Simon D 2006 ed. Fifty key thinkers in Development Routledge, London.

Simon D 2007 Beyond antidevelopment: discourses, convergences, practices Singapore Journal of Tropical Geography 28 205-218.

Slater D 1977 Geography and underdevelopment Antipode 9, 3 1-31.

Slater D 1993 The geopolitical imagination and the enframing of development theory Transactions of the Institute of British Geographers 18 419-437.

Slater D 2011 Latin America and the challenge to imperial reason Cultural Studies 25 450-458.

Sorre M 1952 La géographie de l'alimentation Annales de Géographie 61 184-199.

Souza M A 2007 O mundo do cidadão um cidadão do mundo Hucitec, São Paulo 1996.

Sparke M 2007 Everywhere but always somewhere: critical geographies of the Global South The Global South 1 \& 2 117-126.

Teles de Carvalho A 2009 Josué de Castro e a inclusão da fome nos Estudos Geográficos do Brasil, PhD Dissertation, São Paulo.

Withers C 2004 Constructing the geographical archive Area 34 303-311.

Federico Ferretti \& Breno Viotto Pedrosa, 2018, "Inventing critical development: a Brazilian geographer and his Northern networks", Transactions of the Institute of British Geographers [early view https://onlinelibrary.wiley.com/doi/full/10.1111/tran.12241 ] 
Ziai A 2015 Post-Development: premature burials and haunting ghosts Development and Change $46833-854$.

Federico Ferretti \& Breno Viotto Pedrosa, 2018, "Inventing critical development: a Brazilian geographer and his Northern networks", Transactions of the Institute of British Geographers [early view https://onlinelibrary.wiley.com/doi/full/10.1111/tran.12241 ] 